\title{
The prevalence of nutritional anemia in pregnancy in an east Anatolian province, Turkey
}

\author{
Leyla Karaoglu, Erkan Pehlivan², Mucahit Egri ${ }^{3}$, Cihan Deprem4, Gulsen Gunes², Metin F Genc ${ }^{2}$ and Ismail Temel ${ }^{5}$
}

\begin{abstract}
Background: Anemia is considered a severe public health problem by World Health Organization when anemia prevalence is equal to or greater than $40 \%$ in the population. The purpose of this study was to determine the anemia prevalence with the associated factors in pregnant women and to determine the serum iron, folate and B12 vitamin status in anaemic pregnants in Malatya province.

Methods: This is a cross-sectional survey. A multi-sage stratified probability-proportional-to-size cluster sampling methodology was used. A total of 823 pregnant women from sixty clusters were studied. Women were administered a questionnaire related with the subject and blood samples were drawn. Total blood count was performed within four hours and serum iron, folate and B12 vitamin were studied after storing sera at $-20 \mathrm{C}$ for six months.

Results: Anemia prevalence was $27.1 \%(\mathrm{Hb}<11.0 \mathrm{gr} / \mathrm{dl})$. Having four or more living children $(\mathrm{OR}=2.2)$, being at the third trimester $(O R=2.3)$ and having a low family income $(O R=1.6)$ were determined as the independent predictors of anemia in pregnancy. Anemia was also associated with soil eating (PICA) in the univariate analysis $(p<0.05)$. Of anaemic women, $50.0 \%$ had a transferrin saturation less than $10 \%$ indicating iron deficiency, $34.5 \%$ were deficient in B12 vitamin and $71.7 \%$ were deficient in folate. Most of the anemias were normocytic-normochromic (56.5\%) indicating mixed anemia.

Conclusions: In Malatya, for pregnant women anemia was a moderate public health problem. Coexisting of iron, folate and $B$ vitamin deficiencies was observed among anaemics. To continue anemia control strategies with reasonable care and diligence was recommended.
\end{abstract}

\section{Background}

According to the United Nations (UN) estimates, approximately half of pregnant women suffer from anemia worldwide. Anemia prevalences during pregnancy differed from $18 \%$ in developed countries to $75 \%$ in South Asia [1]. Nutritionally related iron deficiecy is the main cause of anemia throughout the world. It is especially common in women of reproductive age and particularly during pregnancy. The demand for iron increases about six to seven times from early pregnancy to the late pregnancy [2]. Besides poor nutrition, frequent labour, multiparity, abortions, parazitic enfestations, consuming excess tea or coffee after meals determined as the predictors of anemia in reproductive age women [3].

Studies well indicated the association of anemia with maternal morbidity and mortality. Worldwide, anemia

* Correspondence: leyla.karaoglu@rize.edu.tr

1 Public Health Department, Medical School, Rize University, Rize, Turkey Full list of author information is available at the end of the article contributes to $20 \%$ of all maternal deaths [4]. Anemia in pregnancy also lead to premature births, low birth weight, fetal impairment and infant deaths. It reduces the productivity of women. The reduction in women's productivity places an economic burden on the families, communities and the societies [4]. Recently, mental impairment of children who were anaemic in the very begining of their life have been reported. All of those showed the necessity of special control program for anemia in vulnerable population [3-5].

Folate deficiencies since 1960s and B12 vitamin deficiencies since 1990s defined as contributing causes of nutritional anemia [6]. Folate deficiency is common as a result of dietary deficiency or increased demand as in pregnancy. The prevalence of folate deficiency in pregnant patients varies from 1 to $50 \%$. The prevalence is higher among economically deprived patients. B12 vitamin is mostly found in foods of animal origin and deficiency was not reported as a frequent cause of anemia. 
Anemia due to zinc, copper, vitamin A or other vitamin and minerals are also considered in the literature [3,5].

Since 1994, based on the recommendation of UN, experts in World Health Organization (WHO) and other agencies had developed indexes to monitor and evaluate governments' progress in reproductive health. Prevalence of anemia among pregnant women was one of the key indicators of the indexes [7]. Reproductive Risk Index (RRI) was developed by Population Action International (PAI) which is a Non Govermental Organization. RRI was scored countries in a five likert scale from very high risk to very low risk from the stand point of reproductive health. The Index ranks countries by the prevalence of anemia, from low (less than 20 percent of women affected) to very high (60 percent or more affected). In the PAI report, 2001, prevalence of anemia among pregnant women in Turkey was reported to be "high", with between 40 and $60 \%$. Thus, RRI scored Turkeyscored in "low risk" group but not in "very low risk" group which also existed [8]. The prevalence of anemia in pregnancy was $73.9 \%$ according to a nationwide survey conducted in 1974 [9]. Studies conducted in different parts of Turkey after 1995 revealed anemia prevalence between $27 \%$ to $88 \%$ with an avarage $50.0 \%$ [10]. As a problem of public health, anemia was classified as none (less than $5 \%$ ), mild (5 to $19.9 \%$ ), moderate (20 to $39.9 \%$ ) and severe (40\% or more) according to the anemia prevalence at the national level by WHO. Anemia prevalence among pregnant women in Turkey was reported as $40.2 \%$ in WHO report [11]. PAI and WHO estimates seems to be based on those data sources before 2000s.

Prevalence studies were recomended by WHO both for monitoring the progress in reproductive health and to determine the severity of anemia since national iron supplementation program were planned according to the severity $[5,11]$.

The purpose of this study was to determine the anemia prevalence with the associated factors in Malatya, and to determine the serum iron, folate and B12 vitamin status in anaemic pregnant women.

\section{Methods}

\section{Study population}

The studied population was pregnant women who were resident in Malatya province located in eastern Turkey. According to the 2000 cencus total population of Malatya was 853 658. About fifteen thousand live births were reported to Health Directorate from health institutions every year and most of them (70\%) were occured in urban area. According to Turkey Demographic and Health Survey-2008, 76.3\% of pregnant women have received antenatal care at least once in the east Anatolia [12].

\section{Sampling}

A stratified multi-stage probability-proportional-to-size cluster sampling methodology was used in selecting the study population. This method has been used for vaccination coverage and still considered acceptable for community based prevalence studies as a fast survey method for developing countries $[13,14]$. In the first stage of the sampling, Malatya was divided into two stratums as urban and rural. Settlements without a municipality and all villages were recruited as rural area. In Malatya, prenatal care is given by health units. Health units were divided into subpopulations of 2-3 thousands called health houses. Health houses were assigned as clusters (sampling units). The list of all health houses with their populations was obtained from Malatya Health Directorate. Cumulative list of health houses' (seperately in urban and rural areas) populations was created and 30 clusters were selected by systematic sampling method from a random start in each stratum. The target sample size of 900 was allocated to urban and rural areas as $70 \%$ and 30\% respectively. Selecting nine women per cluster in rural (a total of 270 women) and 21 women in urban settlements (a total of 630) was planned. However, due to absence at home, being reluctant to participate and acces difficulties to two villages, 580 pregnant women in urban and 243 women in rural settlements were interviewed reaching a total of 823 women. Thus, the coverage rate was $91.4 \%$. Completion of the first three months of pregnancy was determined as selection criteria. The pregnant women who complied with the criteria were selected randomly by using the list of pregnancy monitoring cards at health houses.

\section{Data collection}

Permission from the Rector of University, the Governor of Malatya and the Director of Malatya Health Directorate was taken to conduct the field survey. Data collection was performed between November 2003 and May 2004 by two teams with three persons in each team. In rural areas, selected women were visited at their homes in association with midwifes while in urban areas they were invited to the health units. After giving voluntary and informed consent, women were administered a face to face questionnaire including items about socio-demographic, fertility characteristics, diet behavior and anemia history. Questionnaire pretest was conducted on a different pregnant women group before the survey. Finally, a total of $10 \mathrm{ml}$ of venous blood sample was obtained from each participant. Two ml blood was drawn into EDTA for complete blood count $(\mathrm{CBC})$ and $8 \mathrm{ml}$ was drawn into plain glass tubes for use in biochemical analysis. 


\section{Laboratuary analysis}

Complete blood count was achieved within four hours with Beckman-Coulter, USA. Iron, folate and B12 vitamin was studied among anaemic women after storing sera at $20^{\circ} \mathrm{C}$ for six months. Radio immunassay method was used to determine folic acid and vitamin B12 levels (Immulite 2000, Diagnostic Product Corporation, Los Angeles, CA,USA). Serum iron concentration and unsaturated iron binding capacity (UIBC) was measured using Olympus System (Au 2700, Germany).

\section{Assessment of anemia, iron, iron binding capacity, folic acid and vitamin B12}

Cutoff values for $\mathrm{Hb}$ and hematocrit concentrations were selected on the basis of gestational age, using WHO criteria. The woman categorized as anaemic if the $\mathrm{Hb}<11.0$ $\mathrm{g} / \mathrm{dl}$. The frequency of the pregnant women with $\mathrm{Hb}$ concentrations $<10.5 \mathrm{~g} / \mathrm{dl}$ at the second trimester was also presented. Manufacturer reference were used to define the normal ranges for mean corpuscular volume (MCV), 80.0-98.0 fl; mean corpuscular hemoglobin $(\mathrm{MCH})$ 27.033.5 pg; mean corpuscular hemoglobin concentration (MCHC) 32.0-36.0 g/dL; and erythrocyte width distribution (RDW) 11.9-14.5\%. Cut-off level used to indicate serum iron, folic acid and vitamin B12 deficiencies were $50 \mu \mathrm{g} / \mathrm{dl}, 3 \mathrm{ng} / \mathrm{ml}$, and $148 \mathrm{pg} / \mathrm{ml}$. respectively according to the literature $[15,16]$. Transferrin saturation was calculated using the equity of serum iron $\times 100 /$ TIBC $($ TIBC $=$ UIBC + serum iron). Transferrin saturation less than $10.2 \%$ defined as low serum transferrin saturation and used as the indicator of iron deficiency anemia $[17,18]$.

\section{Statistical analysis}

Data entry and statistical analysis was performed using the SPSSWIN 9.0 program. Descriptive data are presented as percentages or as means \pm SD. Chi-square test was performed to detect any association between anemia prevalences and independent variables. Mann-Whitney $\mathrm{U}$ and Kruskall Wallis tests wereused in making comparisons between the red blood cell indices. A p value of < 0.05 was considered statistically significant. Backward logistic regression analysis was performed to evaluate the independent association existing between the potential risk factors and anemia. Independent variables that were significant at the $\mathrm{p}=0.05$ level in univariate analysis were included in multivariate analysis to control for confoundings in regression models. Trimester, family income, number of live births, number of living children, family structure, PICA, receving social support were included in regression model as dichotomous variables. The results were presented in odds ratios (OR) and 95\% confidence intervals. $\mathrm{Hb}<11.0 \mathrm{~g} / \mathrm{dl}$ was considered anemia for general sample while doing the statistical analysis.

\section{Results}

The average age of the pregnant women was $26.5 \pm 0.2$ years. The mean ages of anaemic and nonanemic women were similar, 26.9 and 26.4 years respectively $(\mathrm{p}>0.05)$.Of the women, $10.2 \%$ were illeterate, $55.1 \%$ were primary school graduates. The majority were in the second trimester $(63.7 \%)$ and $36.3 \%$ were in third trimester. Of the participants $33.7 \%$ were primipars. The mean number of live births was $1.3 \pm 0.05$ and the mean number of living children was $1.2 \pm 0.05$. The average monthly income was $409 \pm 11.7$ million Turkish Liras (about 272 \$), 52.8\% had a monthly income under minimum wage (303 million Turkish Liras), 12.9\% had received financial support from state and $37.6 \%$ had no health insurance. The average monthly income for anemic and nonanemic women was similar ( $p>0.05$ ). A total of $29.6 \%$ of the women were living in the rural area.

Table 1 shows the mean haematological values and prevalence of anemia by personal characteristics.

The mean values for the whole group for $\mathrm{MCV}, \mathrm{MCH}$, $\mathrm{MCHC}, \mathrm{RDW}, \mathrm{Htc}$ and $\mathrm{Hb}$ were $85.3 \mathrm{fl}, 29.3 \mathrm{pg}, 34.3 \mathrm{~g} / \mathrm{dl}$, $14.0 \%, 33.6 \%$ and $11.5 \mathrm{~g} / \mathrm{dl}$, respectively while the values for anaemic group were $81.1 \mathrm{fl}, 27.5 \mathrm{pg}, 33.8 \mathrm{~g} / \mathrm{dl}, 14.8 \%$, $29.9 \%$ and $10.1 \mathrm{~g} / \mathrm{dl}$, respectively $(\mathrm{p}<0.05)$. All haematological values were lower in anaemic group comparing with the nonanaemic group except the mean RDW value. The mean RDW (14.8\%) was significantly higher among anaemic pregnants. As seen in Table 1, observed differences varied as a result of different haematological means as well as different personal characteristics.

Overall, the anemia prevalence was $27.1 \%$ among the studied pregnant women. Not many women had severe anemia (Hb concentration was $<7.0 \mathrm{~g} / \mathrm{dl}$ in one women or $<8.0 \mathrm{~g} / \mathrm{dl}$ in 3 women).

The proportion of anemia was significantly higher among those women whose monthly family income was less than 500 million TL $(29.1 \%)$ ( $\mathrm{p}<0.05)$. For the subjects who received financial support $(35.8 \%)$ and lived in nuclear families (30.0\%) the occurance rate of anemia was significantly higher $(\mathrm{p}<0.05)$. Anemia was more frequent at the third trimester (37.5\%) than at the second $(21.2 \%)$ $(\mathrm{p}<0.05)$. The proportion of the pregnants with $\mathrm{a} \mathrm{Hb}$ concentration under $10.5 \mathrm{~g} / \mathrm{dl}$ at the second trimester was $12.6 \%$.

Of the participants, 278 (33.8\%) were primigravidas, 318 were nullipars (38.6\%) and $230(27.9 \%)$ were primipars. Anemia prevalences were $25.9 \%, 24.8 \%$ and $27.0 \%$ among them, respectively. There was no statistically significant difference between number of pregnancies and anemia prevalence $(\mathrm{p}>0.05)$. Anemia prevalence was highest in those with four and more live births (42.3\%) and in women with four or more living children (44.1\%) $(\mathrm{p}<0.05)$. 
Table 1: Distribution of mean blood indices and anemia prevalence by personal characteristics

\begin{tabular}{|c|c|c|c|c|c|c|c|c|}
\hline & & & Mean & & & & & \\
\hline Personal characteristics & MCV (fl) & MCH (pg) & $\mathrm{MCHC}(\mathrm{g} / \mathrm{dl})$ & RDW(\%) & Htc\% & $\mathrm{Hb}(g / d l)$ & Anemia prevalence $\#$ \% (n) & Total N \\
\hline \multicolumn{9}{|l|}{ Age } \\
\hline $15-19$ & 84.9 & 29.1 & 34.2 & 14.2 & 33.6 & 11.5 & $24.3(17)$ & 70 \\
\hline $20-24$ & 85.5 & 29.5 & 34.2 & 13.9 & 33.5 & 11.5 & $27.6(77)$ & 279 \\
\hline $25-29$ & 84.9 & 29.2 & 34.3 & 13.9 & 33.8 & 11.6 & $23.9(56)$ & 234 \\
\hline $30-34$ & 85.5 & 29.3 & 34.3 & 14.0 & 33.5 & 11.5 & $30.0(48)$ & 160 \\
\hline $35-39$ & 85.5 & 29.5 & 34.4 & 14.2 & 33.0 & 11.4 & $31.8(21)$ & 66 \\
\hline$\geq 40$ & 85.0 & 28.9 & 33.9 & 14.6 & 33.4 & 11.4 & $28.6(4)$ & 14 \\
\hline \multicolumn{9}{|l|}{ Education } \\
\hline Illeterate & 84.8 & 29.2 & 34.3 & 14.3 & 33.1 & 11.4 & $35.7(30)$ & 84 \\
\hline Literate \& primary completed & 85.2 & 29.2 & 34.2 & 13.9 & 33.6 & 11.5 & $26.2(129)$ & 492 \\
\hline Secondary school \& higher education completed & 85.6 & 29.7 & 34.3 & 14.0 & 33.6 & 11.5 & $25.9(64)$ & 247 \\
\hline Family income (million TL) & & $* 1$ & & & & & $* 1$ & \\
\hline$\leq 250$ & 85.4 & 29.3 & 34.3 & 13.8 & 33.6 & 11.5 & $25.8(74)$ & 287 \\
\hline $251-500$ & 84.6 & 29.0 & 34.2 & 14.1 & 33.4 & 11.4 & $31.8(114)$ & 358 \\
\hline $501-750$ & 86.3 & 30.6 & 34.5 & 13.9 & 33.8 & 11.7 & $17.3(13)$ & 75 \\
\hline $751-1000$ & 86.1 & 29.6 & 34.3 & 14.0 & 34.0 & 11.7 & $21.3(16)$ & 75 \\
\hline$\geq 1000$ & 86.9 & 30.0 & 34.5 & 14.6 & 33.9 & 11.7 & $21.4(6)$ & 28 \\
\hline Social support & & & & & & & $* 1$ & \\
\hline Receiving & 85.5 & 29.4 & 34.3 & 13.9 & 32.9 & 11.3 & $35.8(38)$ & 106 \\
\hline Not receiving & 85.2 & 29.3 & 34.3 & 14.0 & 33.7 & 11.5 & $25.8(185)$ & 717 \\
\hline Family structure & & & $* 1$ & $* 1$ & & & $* 1$ & \\
\hline Nuclear & 85.2 & 29.4 & 34.3 & 14.1 & 33.5 & 11.5 & $29.9(144)$ & 482 \\
\hline Extended & 85.4 & 29.2 & 34.2 & 13.9 & 33.7 & 11.5 & $23.2(79)$ & 341 \\
\hline
\end{tabular}


Table 1: Distribution of mean blood indices and anemia prevalence by personal characteristics (Continued)

\begin{tabular}{|c|c|c|c|c|c|c|c|c|}
\hline Second (4-6 months) & 85.9 & 29.7 & 34.5 & 13.9 & 33.8 & 11.7 & $21.2(111)$ & 524 \\
\hline Third (7-9 months) & 84.2 & 28.6 & 33.9 & 14.2 & 33.1 & 11.2 & $37.5(112)$ & 299 \\
\hline Number of living children & & & & & & & $* 1$ & \\
\hline 0 & 85.4 & 29.4 & 34.2 & 14.0 & 33.9 & 11.6 & $25.0(85)$ & 340 \\
\hline 1 & 85.4 & 29.3 & 34.2 & 14.0 & 33.5 & 11.5 & $26.9(61)$ & 227 \\
\hline 2 & 85.0 & 29.2 & 34.3 & 14.0 & 33.4 & 11.5 & $29.0(40)$ & 138 \\
\hline 3 & 85.7 & 29.7 & 34.6 & 13.9 & 33.7 & 11.6 & $18.6(11)$ & 59 \\
\hline$\geq 4$ & 84.2 & 29.0 & 34.3 & 14.1 & 32.4 & 11.1 & $44.1(26)$ & 59 \\
\hline PICA & & & & & & & $* 1$ & \\
\hline Positive & 82.1 & 27.9 & 33.9 & 14.9 & 32.7 & 11.1 & $37.0(34)$ & 92 \\
\hline Negative & 85.7 & 29.5 & 34.3 & 13.9 & 33.7 & 11.6 & 25.9(189) & 731 \\
\hline \multicolumn{9}{|c|}{ Red meat, poultry, fish consumption } \\
\hline 1 portion everyday & 85.5 & 29.4 & 34.3 & 14.1 & 33.9 & 11.6 & 19.4(13) & 67 \\
\hline Less frequently & 85.2 & 29.3 & 34.3 & 14.0 & 33.5 & 11.5 & $27.8(210)$ & 756 \\
\hline \multicolumn{9}{|c|}{ Fruit and vegetables consumption } \\
\hline 1 portion everyday & 85.8 & 29.5 & 34.3 & 13.9 & 33.7 & 11.6 & $24.3(84)$ & 346 \\
\hline Less frequently & 84.9 & 29.2 & 34.2 & 14.1 & 33.5 & 11.5 & 29.1(139) & 477 \\
\hline \multicolumn{9}{|l|}{ Drinking tea at breakfast } \\
\hline Yes & 85.2 & 29.2 & 34.2 & 14.0 & 33.5 & 11.5 & $27.7(205)$ & 741 \\
\hline No & 86.3 & 30.6 & 34.6 & 14.1 & 33.9 & 11.7 & $22.0(18)$ & 82 \\
\hline Total & 85.3 & 29.3 & 34.3 & 14.0 & 33.6 & 11.5 & 27.1 & 823 \\
\hline
\end{tabular}

${ }^{*} \mathrm{P}<0.05$, chi-square test

1 Income levels were categorized according to the Turkish Statistical

Institue "household budget survey"s minimum income in 2004

$\# \mathrm{Hb}<11.0 \mathrm{~g} / \mathrm{dl}$ 
There was no significant relationship between the prevalence of anemia and the women' age, educational level and dietary behaviors except soil eating by univariate analysis.

Of the pregnant women, $90.0 \%$ drank tea at breakfast, $40.2 \%$ consumed egg, $8.1 \%$ consumed red meat, poultry or fish and $42.0 \%$ consumed fruit and vegetables daily. Soil eating was reported by $11.2 \%$. The percentage of soil eating was higher among illeterate (19.0\%) and lower among the group who had graduated from secondary school or had higher education $(5.3 \%)(\mathrm{p}<0.01)$. Anemia prevalence was higher among those women who ate soil $(37.0 \%)(\mathrm{p}<0.05)$. Daily animal protein consumption frequency was $4.2 \%$ among the low-income women $(<$ $332 \$$ ), whereas it was $39.3 \%$ among high-income women $(\geq 332 \$)(p<0.05)$. Similarly, daily fruit and vegetables consumption frequency was more frequent (60.7\%) among high-income and less frequent (28.6\%) among low-income women $(\mathrm{p}<0.05)$.

Significantly associated variables in univariate analysis were put into backward stepwise logistic regression analysis to determine the independent predictors of anemia at pregnancy (Table 2). After logistic regression analysis, having four or more living children $(\mathrm{OR}=2.2)$, being at third trimester $(\mathrm{OR}=2.3)$ and having a low family income $(\mathrm{OR}=1.6)$ were determined as the independent predictors of anemia during pregnancy.

Percentage distribution of micronutrient deficiencies and mean haematological values among anaemic pregnant women by some personal characteristics were presented in Table 3.

Of the anaemic women, $12.6 \%$ had UIBC level $>300 \mu \mathrm{g} /$ $\mathrm{dl}, 68.2 \%$ had TIBC level $>480 \mu \mathrm{g} / \mathrm{dl}, 50.2 \%$ had a transferrin saturation less than $10.2 \%$ (data not shown) and $57.0 \%$ had serum Fe level $<50 \mu \mathrm{g} / \mathrm{L}$ (Table 3). Folate and B12 vitamin deficiencies were found in $71.7 \%$ and $34.5 \%$ of the anaemic women, respectively. Only a small number (11) of participants had serum B12 level $<100 \mathrm{pg} / \mathrm{dl}$ (4.9\%). The proportion of folate deficiency was significantly higher among women who drank tea at breakfast $(74.1 \%)$ and significantly lower among women who were under iron medication $(42.6 \%)(\mathrm{p}<0.05)$. B12 vitamin deficiency was more prevalent among women with more than two living children and iron deficiency was more prevalent among women with a monthly family income less than 500 million TL $(<332 \$)(\mathrm{p}<0.05)$. The proportion of folate deficiency was $72.9 \%$ among anaemic nullipars (Table 3 ) and $72.2 \%$ among anaemic primigravidas (data not shown).

In analyzing the red blood cell count, significant differences were observed in the mean values for $\mathrm{MCV}, \mathrm{MCH}$, $\mathrm{MCHC}$ and RDW by soil eating and in the mean value for RDW by current use of iron treatment $(\mathrm{p}<0.05)$. The mean RDW value was higher among women with PICA (15.5\%) and among those women who were under iron medication (15.5\%). The mean value for MCV was close to the lower limit $(81.1 \mathrm{fl})$ among anaemics (minimum: 57.9, maximum: 101.5). Among women with three children the mean value for $\mathrm{MCV}$ was $83.9 \pm 10.1 \mathrm{fl}$ and, the proportions of B12 vitamin and folate deficiencies were also higher in this category indicating the presence of mixed anemia (Table 3).

Of the anaemic pregnants, $38.1 \%$ had a microcytichypochromic anemia $(\mathrm{MCV}<80 \mathrm{fl} \& \mathrm{MCH}<27 \mathrm{pg})$, $56.5 \%$ had a normocytic-normochromic (MCV and MCH within normal range), $0.9 \%$ had a macrocytic (MCV > $98.0 \mathrm{fl}$ ) anemia and $4.5 \%$ had combined morphologic type of anemia. Iron deficiency was the most prevalent micronutrient deficiency $(67.1 \%)$ among microcytic-hypochromic anemia $(\mathrm{p}<0.05)$ and, folat deficiency was common in all morphologic types ( $p>0.05)$ (Table 4).

Table 2: The predictors of anemia during pregnancy (logistic regression analysis)

\begin{tabular}{|c|c|c|c|c|c|}
\hline Variables & Odds Ratios & Confidence Interval (95.0\%) & B coefficient & Pvalue & $\mathbf{N}$ \\
\hline \multicolumn{6}{|l|}{ Number of living children } \\
\hline$<4$ & 1 & - & - & - & 764 \\
\hline$\geq 4$ & 2.180 & $1.251-3.797$ & 0.779 & 0.006 & 59 \\
\hline \multicolumn{6}{|l|}{ Gestational age } \\
\hline Second trimester & 1 & - & - & - & 524 \\
\hline Third trimester & 2.254 & $1.639-3.099$ & 0.813 & 0.001 & 299 \\
\hline \multicolumn{6}{|l|}{ Family income } \\
\hline$\geq 500$ million TL ( $\geq 332 \$)$ & 1 & - & - & - & 178 \\
\hline$<500$ million TL $(<332 \$)$ & 1.572 & $1.037-2.383$ & 0.452 & 0.033 & 645 \\
\hline
\end{tabular}


Table 3: Frequency of micronutrient deficiences and mean haematological values among anaemic pregnants by some personal characteristics

\begin{tabular}{|c|c|c|c|c|c|c|c|c|c|c|}
\hline \multirow[t]{2}{*}{ Personal characteristics } & \multirow[t]{2}{*}{ Total N } & \multicolumn{3}{|c|}{ Micronutrient deficiencies (\%) } & \multicolumn{6}{|c|}{ Mean ( \pm SD) haematological values } \\
\hline & & İron & Folate & B12 & $\mathrm{Hb}(\mathrm{g} / \mathrm{dl})$ & Htc(\%) & $\operatorname{MCV}(f \mathrm{fl})$ & $\mathrm{MCH}(\mathrm{pg})$ & MCHC (g/dl) & RDW(\%) \\
\hline Number of living children & & & & * & & & & & & \\
\hline 0 & 85 & 55.3 & 72.9 & 29.4 & $10.1 \pm 0.7$ & $30.1 \pm 1.8$ & $81.0 \pm 8.0$ & $27.3 \pm 3.2$ & $33.6 \pm 1.1$ & $15.0 \pm 2.6$ \\
\hline 1 & 61 & 52.5 & 67.2 & 24.6 & $10.1 \pm 0.8$ & $29.8 \pm 1.9$ & $81.0 \pm 8.2$ & $27.5 \pm 3.5$ & $33.8 \pm 1.3$ & $14.8 \pm 2.4$ \\
\hline 2 & 40 & 60.0 & 72.5 & 45.0 & $10.1 \pm 0.7$ & $29.9 \pm 2.1$ & $81.3 \pm 7.3$ & $27.6 \pm 2.9$ & $33.8 \pm 0.9$ & $14.6 \pm 1.7$ \\
\hline 3 & 11 & 63.6 & 81.8 & 54.5 & $10.1 \pm 0.6$ & $29.6 \pm 1.1$ & $83.9 \pm 10.1$ & $28.7 \pm 4.0$ & $34.1 \pm 1.0$ & $13.9 \pm 1.7$ \\
\hline$\geq 4$ & 26 & 65.4 & 73.1 & 50.0 & $10.1 \pm 0.7$ & $29.8 \pm 1.8$ & $80.6 \pm 7.6$ & $27.4 \pm 3.1$ & $33.9 \pm 1.0$ & $14.9 \pm 1.8$ \\
\hline Family income ${ }^{2}$ (million TL) & & * & & & & & & & & \\
\hline$\leq 250$ & 74 & 62.2 & 71.6 & 37.8 & $10.1 \pm 0.6$ & $29.8 \pm 1.7$ & $82.2 \pm 7.4$ & $28.0 \pm 3.1$ & $33.9 \pm 1.1$ & $14.3 \pm 1.9$ \\
\hline $251-500$ & 114 & 59.6 & 75.4 & 33.3 & $10.1 \pm 0.8$ & $29.9 \pm 2.0$ & $79.9 \pm 8.1$ & $27.0 \pm 3.3$ & $33.7 \pm 1.1$ & $15.0 \pm 2.5$ \\
\hline $501-750$ & 13 & 30.8 & 69.2 & 53.8 & $10.2 \pm 0.6$ & $30.6 \pm 1.9$ & $81.6 \pm 9.1$ & $27.3 \pm 3.5$ & $33.7 \pm 1.2$ & $15.2 \pm 1.9$ \\
\hline$\geq 751$ & 22 & 40.9 & 54.5 & 18.2 & $11.7 \pm 0.7$ & $34.0 \pm 1.9$ & $86.4 \pm 7.9$ & $29.7 \pm 3.2$ & $34.3 \pm 1.2$ & $14.2 \pm 2.3$ \\
\hline PICA & & & & & & & * & * & * & * \\
\hline Positive & 34 & 70.6 & 82.4 & 41.2 & $9.8 \pm 0.9$ & $29.5 \pm 2.4$ & $77.0 \pm 7.8$ & $25.8 \pm 3.2$ & $33.4 \pm 1.1$ & $15.5 \pm 2.6$ \\
\hline Negative & 189 & 54.5 & 69.8 & 33.3 & $10.2 \pm 0.7$ & $30.0 \pm 1.7$ & $81.9 \pm 7.8$ & $27.9 \pm 3.2$ & $33.8 \pm 1.1$ & $14.7 \pm 2.1$ \\
\hline Drinking tea at breakfast & & & * & & & & & & & \\
\hline Yes & 205 & 58.0 & 74.1 & 35.6 & $10.1 \pm 0.7$ & $29.9 \pm 1.8$ & $81.0 \pm 7.8$ & $27.4 \pm 3.2$ & $33.8 \pm 1.1$ & $14.8 \pm 2.3$ \\
\hline No & 18 & 44.4 & 44.4 & 22.2 & $10.1 \pm 0.8$ & $30.0 \pm 2.3$ & $82.6 \pm 9.3$ & $28.0 \pm 3.9$ & $33.8 \pm 1.2$ & $14.9 \pm 1.9$ \\
\hline \multicolumn{11}{|c|}{ Red meat, poultry, fish consumption } \\
\hline 1 portion everyday & 146 & 93.8 & 96.8 & 92.5 & $10.1 \pm 0.8$ & $30.0 \pm 1.6$ & $81.3 \pm 5.9$ & $27.2 \pm 2.7$ & $33.5 \pm 1.5$ & $15.6 \pm 2.8$ \\
\hline Less frequently & 77 & 94.5 & 93.1 & 97.4 & $10.1 \pm 0.7$ & $29.9 \pm 1.9$ & $81.1 \pm 8.1$ & $27.5 \pm 3.3$ & $33.8 \pm 1.1$ & $14.7 \pm 2.2$ \\
\hline \multicolumn{11}{|l|}{ Fruit \& vegetables consumption } \\
\hline 1 portion everyday & 63 & 57.3 & 66.7 & 65.1 & $10.2 \pm 0.7$ & $30.0 \pm 1.8$ & $82.2 \pm 7.0$ & $27.9 \pm 3.0$ & $33.9 \pm 1.1$ & $14.7 \pm 1.8$ \\
\hline Less frequently & 160 & 66.1 & 60.6 & 57.1 & $10.1 \pm 0.7$ & $29.9 \pm 1.9$ & $80.5 \pm 8.4$ & $27.2 \pm 3.4$ & $33.7 \pm 1.1$ & $14.9 \pm 2.5$ \\
\hline Current use of iron treatment & & & * & & & & & & & * \\
\hline Yes & 47 & 46.8 & 42.6 & 29.8 & $10.1 \pm 0.9$ & $29.7 \pm 2.1$ & $80.0 \pm 9.2$ & $27.2 \pm 3.8$ & $33.9 \pm 1.2$ & $15.5 \pm 2.4$ \\
\hline No & 176 & 59.7 & 79.5 & 35.8 & $10.1 \pm 0.7$ & $30.0 \pm 1.8$ & $81.5 \pm 7.6$ & $27.6 \pm 3.1$ & $33.7 \pm 1.1$ & $14.6 \pm 2.2$ \\
\hline Total & 223 & 57.0 & 71.7 & 34.5 & $10.1 \pm 0.7$ & $29.9 \pm 1.9$ & $81.1 \pm 7.9$ & $27.5 \pm 3.3$ & $33.8 \pm 1.1$ & $14.8 \pm 2.3$ \\
\hline
\end{tabular}

2 Family income category reduced in four groups since the number in the fifth group was small, * $\mathrm{P}<0.05$, Chi-square, Mann-Whitney $\mathrm{U}$ test, Kruskall Wallis tests 
Table 4: Distribution of micronutrient deficiencies by morphologic type of anemia

\begin{tabular}{|c|c|c|c|c|}
\hline \multirow[t]{3}{*}{ Morphologic type of anemia } & \multicolumn{3}{|c|}{ Micronutrient deficiencies } & \multirow[t]{2}{*}{ Total } \\
\hline & Iron & Folat & B12 vitamin & \\
\hline & n(\%) & $n(\%)$ & $n(\%)$ & n(\%) \\
\hline Microcytic-hypochromic anemia (MCV < 80 MCH < 27) & $57(67.1)^{*}$ & $66(77.6)$ & $27(31.8)$ & $85(38.1)$ \\
\hline Normocytic-normochromic anemia (MCV and $\mathrm{MCH}$ within normal range) & $65(51.6)$ & $87(69.0)$ & $47(37.3)$ & $126(56.5)$ \\
\hline Macrocytic (MCV>98) & $1(50.0)$ & $1(50.0)$ & $0(0.0)$ & $2(0.9)$ \\
\hline Others (Kombined morphology) & $4(40.0)$ & $6(60.0)$ & $3(30.0)$ & 10(4.5) \\
\hline Total & $127(57.0)$ & $160(71.7)$ & $77(34.5)$ & $223(100.0)$ \\
\hline
\end{tabular}

Overall, 27.1\% of the pregnant women were under iron medication and $10.9 \%$ were taking both iron and folic acide supplements. Of the women, $52.9 \%$ had received iron therapy at least once in their lifetime. Being under iron medication was significantly different between family income categories. Of the pregnant women in the highest income category, $71.4 \%$ were under iron medication while the proportion was only $13.9 \%$ in the lowest income category $(\mathrm{p}<0.05)$. Of the anaemic pregnants, $21.1 \%$ took iron supplements, $11.7 \%$ took both folate and iron supplements and, $6.3 \%$ vitamin tablets. Of the subjects with a monthly family income $<500$ millionTL, $18.1 \%$ took iron supplements while $37.1 \%$ of the subjects in higher income group took iron supplements $(\mathrm{p}<0.05)$. Women with no health insurance were less likely (15.7\%) than the insured to receive iron supplements $(\mathrm{p}<0.05)$.

\section{Discussion}

The study conducted in Malatya, which is an eastern Anatolian province with 800000 inhabitants, showed a moderate prevalence of anemia (27.1\%). Our findings did not correlate with the results reported by PAI and WHO which indicated that pregnant women in Turkey have had severe anemia $[8,11]$. Our results also notice that anemia trends might have changed in Turkey and a nationwide anemia study is necessary for determining the new anemia status and for international notification. As a matter of fact, the reduction in anemia prevalence from that projected earlier in 1970s is expectable since there was a rapid socio-economic growth of the Turkish population over the past two-three decades which had a major impact on both health status and disease patterns throughout the country and particularly in east Anatolia. Since 1985, governments in colloboration with interna- tional organizations (UNICEF) conducted programs related to mother and child health such as safe motherhood, antenatal care, nutrition education of the public and food aid to the the low income families. Human resouces, education, industry, agriculture and health sector was improved through national development plans and, Eastern Anatolian Project including Malatya since 1997 [19-21].

Even though the study showed $27.1 \%$ prevalence, this is higher than the prevalences in European countries (25.1\%) and in Americas (24.1\%) or averaging 18\% in developed countries [5,11]. Therefore, it is necessary to continue anemia control programs.

Anemia prevalence in our study was also lower than those reported from different parts of the country such as $29.4 \%$ in Afyon [22] and $42.4 \%$ in Elaziğ provinces, the latter is in the eastern Anatolia near Malatya [23].

Socio-economic status is a known determinant of anemia. In this study, anemia was more prevalant among those women who received financial support $(\mathrm{p}<0.05)$ and who had a low monthly family income $(\mathrm{OR}=1.6)$. The majority of anaemic pregnants lived in nuclear rather than extended families which might seem paradoxical. As a result of industrialization, urbanization and internal migration, people are more likely to be living in nuclear households in Turkey, recently [19,21]. However they might be low income families that immigrated for a better life. Family economics and nutrition related problems need to be investigated in detail in such households to determine the contributing effects of social structure and life styles on morbidity. Anemia prevalence was 2.3 times more prevalant at third trimester; The $21.2 \%$ prevalence of anemia at the second trimester increased to $37.5 \%$ at the third trimester comparable to the literature [24-26]. 
This might be due to hemodilution but, it might also indicate poor prenatal care.

Anemia was 2.2 (OR) times more prevalent in women with four or more living children than in women with fewer children. Multiparity may induce anemia by reducing maternal iron reserves at every pregnancy and by causing blood loss at each delivery. The mean number of living children was 1.2 in our study. It was reduced to 2.4 from 2.7 between 1993 and 2003 due to the implementation of family planning services and safe motherhood programs countrywide after 1980s [19,27]. Effective implementation of these programs in Malatya might be reason for the low anemia prevalence in our study from that reported in 1970s. However, we did not observe a homogeneous increase in anemia prevalence with the increase in number of living children by univariate analysis (Table 1). About one fourth of primigravidas, nullipars and primipars were anaemic in our study. The nonhomogeneity with respect to parity was seemed to be a result of high prevalence of folate deficiency among anaemic women (71.7\%).

The study showed that one pregnant women out of ten was eating soil and anemia was more prevalant among soil eaters (37.0\%). Soil eating (PICA) is known to be an old problem among Turkish women and it is common in many underdeveloped countries [28]. İt is still debate whether soil eating causes anemia or anemia leads soil eating. Zinc or other mineral deficiencies may contribute to PICA $[29,30]$. The frequencies of iron, folate, and B12 vitamin deficiencies among women with PICA were $70.6 \%, 82.4 \%$ and $41.2 \%$, respectively. Thus, questioning PICA at prenatal visits and laboratory examination of pregnant women with PICA is recommended.

It was stated in the literature that tea consumption and low intake of red meat were associated with anemia [3133]. Some studies emphasized that tea reduces iron absorbtion but does not influence iron status in people with adequate iron stores [34-37]. Meat is a good source of high quality protein, iron and zinc and of all the B-vitamins except folic acid. Meat consumption was reported to be $21 \mathrm{~kg} /$ capita/year for Turkey, $124 \mathrm{~kg} /$ capita/year for USA and about $100 \mathrm{~kg} / \mathrm{capita} /$ year for European countries [38]. These data might explain the lower anemia prevalences among those developed countries. We found that $90 \%$ of pregnants drank tea at breakfast and only $8 \%$ consumed animal protein daily. Our study did not reveal a significant association with tea and meat consumption though anemia was less prevalent in women who consumed one portion of animal protein daily $(19.4 \%)$ and who did not drink tea at breakfast (22.0\%). Consuming tea between meals and simultaneously consuming vitamin $\mathrm{C}$ and/or meat, fish and poultry were the main dietary recommendations to prevent anemia [37]. A recent publication reported that green and black tea had the potantial risk of diminished folic acid bioavailability [39]. Drinking tea at breakfast and just after the meal are common unhealthy dietary habits in Turkey. Thus, continous nutrition education and monitoring programs should be developed at all levels according to the recommendations to combat anemia.

Among the anaemic women, half had a transferin saturation less than $10 \%$ indicating iron deficiency, one third (34.5\%) were deficient in B12 vitamin and more than two third (71.7\%) were deficient in folate. Pehlivanoğlu and Koç reported higher percentages of iron deficiencies among anaemic pregnant women in İstanbul; $68.5 \%$ and $62 \%$, respectively [40,41]. High percentages of pregnants were at risk for deficiencies of vitamin B12 (48.8\%) and folate $(59.7 \%)$ in early pregnancy and vitamin B12 (80.9\%) and folate (76.4\%) during late pregnancy in Açkurt's study [10]. Koc et al. reported higher B12 deficiency (48\%) and lower folic acid deficiency (12\%) than ours [41]. All these studies were conducted at clinics, and so to determine the contribution of vitamin deficiencies to anemia a population based survey is necessary. İron deficiency defined as the most frequent form of the nutritional anemia in pregnant women in the literature followed by folate and B12 vitamin deficiencies $[3,6,24,42]$. Folate deficiency was more frequent than iron deficiency in our study. In a study conducted in a western city in Turkey, serum folic acid levels were found to be marginal for $46 \%$ ( 3 to 5.9 ng/ $\mathrm{mL})$ and at deficient levels for $16.3 \%(<3 \mathrm{ng} / \mathrm{mL})$ among adolescent girls [43]. Our study showed high prevalences of folate deficiency even in primigravidas and nullipars raised doubt if there was a common folate deficiency problem in the population. The prevalence of neural tube defects (NTDs) in Turkey has been reported to be 30.1 per 10000 births [44]. In order to decrease births affected by NTD, the fortification of all enriched grain products with folic acid have been implemented in USA since 1998 and folate deficiency in population was reduced. Further studies recommended to determine the folate deficiency burden in the general population and to decide if fortification of appropiate foods like wheat flour which is the main staple food of the country with folic acid or with other micronutrients as tried in USA, Canada and Chile [45].

We found that, most of the anemias were normocyticnormochromic (56.5\%) and, 38.1\% were microcytichypochromic. Despite the high propotions of folate deficiency in anaemic women, only 2 cases $(0.9 \%)$ were macrocytic. It was stated in the literature that folate and B12 vitamin deficiencies caused macrocytic anemia, however concurrent presence of iron deficiency resulted in normocytic anemia [3]. The mean haematological values for the anaemic women in our study confirmed this inference (Table 3). In anaemic women, iron and folate deficiencies were both common, mean $\mathrm{MCV}$ value was close to the 
lower limit, mean $\mathrm{Hb}$ value was $10.1 \mathrm{~g} / \mathrm{dl}$, and RDW was $14.8 \%$ showing that there was a mixed anemia with the dominant cause being iron deficiency [46].

The limitations of the study should be emphasized particularly in relation with serum iron, B12 vitamin and serum folate. Fasting or nonfasting status of women was not questioned at drawning of blood samples which the results might have altered. They were studied only in anaemic women so that any comparison with non-anaemic women could not be done. Serum transferrin and red blood cell folate are better indicators of iron and folate deficiency which our budget could not afford. For the serum B12, we could comment that all forms of vitamin B12 in the serum might be detected so the deficiency was high. Also it was observed that serum B12 vitamin cutoff levels for pregnant women were not certain in the literature and being under iron medication might inluence the mean blood indices. Enfections were not questioned either.

In conclusion there was a moderate anemia problem both in the second and third trimesters among pregnant women in Malatya, Turkey. The main predictors of anemia were low family income, being in the third trimester and having four or more living children. Of the anaemic women half was iron deficient, one third was B12 vitamin and two third was folate deficient. The most frequent morphologic type of anemia was normocytic-normochromic anemia and, the complete blood count suggested that anemia was caused by mixed micronutrient deficiency. Only one fifth of the anaemic women were under iron medication. Ten percent of the women were eating soil and anemia was more prevalent among soil eaters. PICA was more prevalent among low-income anaemic women, whereas consuming animal protein daily and being under iron medication were less frequent in lowincome anaemic women.

World health Organization recommended supplementation of all pregnant women with a daily dose of $60 \mathrm{mg}$ iron and $400 \mathrm{~g}$ folate to control iron deficiency anemia as a primary prevention method [47]. Disadvantages of iron supplementation include poor compliance with treatment, adverse gastrointestinal effects, low absorbsition of iron supplements due to taken with meals or with other minerals but not seperately. However, it was shown that daily iron supplements reduce low birth weight incidence. It is suggested that this reduction leads decrease in chronic diseases and could reduce health care costs [48]. B12 vitamin deficiency association with hematological and neurological problems in infants and chronic diseases in adults including thromboembolic conditions have been reported in the literature $[49,50]$. Due to that, we recommended daily iron supplementation program with the supplementation of folate and B12 vitamine. Turkey had begun routine iron supplementation to the pregnant women all over the country in 2005 after the survey [51]. The program should be given attention because there is a possibility of neglecting the appropiate and comprehensive examination and therapy of anaemic women due to iron supplement given. Therefore, educating the health personnel on the subject is necessary. Some developed countries supply food rich in iron, calcium, protein and vitamins to the pregnant women. Sweden and USA are among the developed countries conducted such programs $[14,52,53]$. Access to the lowincome anaemic pregnant women and food aid programs towards them need to be considered as immediate recipe in Turkey.

\section{Conclusions}

There was a moderate anemia problem in pregnant women in Malatya, Turkey (27.1\%). One fourth of women enter pregnancy with anemia. Low family income (< $332 \$$ ), gestational age (third trimester) and multiparity were the main predictors of anemia. The main morphologic type of anemia was normocytic-normochromic. Coexisting of iron, folate and $\mathrm{B}$ vitamin deficiencies was observed among anaemics. Continuing of daily iron supplementation program with folate supplementation in the beginning of pregnancy and food aid programs towards low-income women was recommended.

\section{Competing interests}

The authors declare that they have no competing interests.

\section{Authors' contributions}

LK participated in the design of the study, perfomed the data collection, performed the statistical analysis and served as the lead author of the manuscript. EP participated in the design of the study, helped to draft the manuscript. ME participated in the design of the study and helped performing the statistical analysis. CD helped to collect data. GG participated in drafting the manuscript. MEF participated in drafting the manuscript. IT carried out the immunoassays and complete blood count. All authors read and approved the final manuscript.

\section{Acknowledgements}

This paper presented the findings related to anemia in pregnancy which was a component of a comprehensive research project on the health of pregnant women in Malatya. Findings related to violence, rubella seroprevalence and iodine deficiency in the same sample had already been published as seperate articles. The study was supported by Inonu University Research Projects Fund. The authors gratefully acknowledge the help and cooperation extended by the administrators of Malatya Health Directorate, participated Health Units' general practioners and midwives. The authors also acknowledge the iron support by the agencies Koçak İlaç and Abdi İbrahim İlaç. The anaemic pregnant women were given therapy during the study.

\section{Author Details}

1 Public Health Department, Medical School, Rize University, Rize, Turkey, 2Public Health Department, Medical School, Inonu University, Malatya, Turkey, 3Public Health Department, Medical School, Gaziosmanpaşa University, Tokat, Turkey, ${ }^{4}$ Enfectious Diseases Department, Ankara Health Directorate,

T.R.Ministry Of Health, Ankara, Turkey and 5Department of Biochemistry, Medical School, Inonu University, Malatya, Turkey

Received: 29 January 2010 Accepted: 10 June 2010

Published: 10 June 2010 


\section{References}

1. Wang S, An L, Cochran SD: Women. In Oxford textbook of public health Fourth edition. Edited by: Detels R, McEwen J, Beaglehole R, Tanaka H. United States: Oxford University Press; 2002:1587-601.

2. Christensen RD, Ohls RK: Anaemias unique to pregnancy and the perinatal period. In Wintrobe's clinical hematology Volume 2. 11 th edition. Edited by: Greer JP, Foerster J, Lukens NJ, Rodgers GM, Paraskevas F, Glader B. USA: Lippincott Williams and Wilkins; 2004:1467-1486.

3. Nutritional anaemia [http://www.sightandlife.org/pdf/NAbook.pdf

4. Micronutrient deficiencies iron deficiency anaemia [http:// www.who.int/nutrition/topics/ida/en/index.html

5. Allen LH: Pregnancy and iron deficiency: Unresolved issues. Nutrition Reviews 1997, 55(4):91-101.

6. Van den Broek NR: Anaemia and micronutrient deficiencies. BrMed Bull 2003, 67:149-60.

7. What about Reproductive Health? Improving the Success of Development Cooperation [http://www.euroresources.org/fileadmin/ user upload/EC guide/Delegation handbook small.pdf

8. The PAI report card 2001: a world of difference: sexual and reproductive health \& risks [http://www.populationaction.org/ Publications/Reports/A World of Difference/AWOD English.pdf

9. Koksal O: Nutrition in Turkey National nutrition-health and food consumption survey of Turkey. 1974. Ankara: UNICEF;1977

10. Pekcan G, Karaagaoglu N: State of nutrition in Turkey. Nutr Health 2000, 14(1):41-52

11. WHO Global Database on Anaemia: Worldwide prevalence of anaemia 1993-2005. [http://whqlibdoc.who.int/publications/2008/ 9789241596657 eng.pdf

12. Ergöçmen BA, Tezcan S, Çăgatay P: Üreme Sağliği (Reproductive Health). In Hacettepe Üniversitesi Nüfus Bilimleri Enstitüsü (2009) Türkiye Nüfus ve Sağlik Araştirmasi, 2008 (Hacettepe University Institute of Population Studies (2009) Turkey Demographic and Health Survey,2008) Edited by: Hacettepe Üniversitesi Nüfus Bilimleri Enstitüsü, Sağ|lk Bakanlığı Ana Çocuk Sağ|lğı ve Aile Planlaması Genel Müdürlüğü, Başbakanlık Devlet Planlama Teşkilatı Müsteşarlığı ve TUBİTAK. Ankara, Türkiye: Hacettepe Üniversitesi Hastaneleri Basımevi; 2009:143-158.

13. Facilitator guide for the EPI coverage survey 1991 [http://www.who.int/ immunization monitoring/routine/ Facilitator guide EPI coverage survey.pdf].

14. Milligan P, Njie A, Bennett S: Comparison of two cluster sampling methods for health surveys in developing countries. Int J Epidemiol 2004, 33(3):469-76.

15. Van Den Broek NR, Letsky EA: Etiology of anemia in pregnancy in south Malawi. Am J Clin Nutr 2000, 72:247-56.

16. The prevalence of anaemia in women [http://whqlibdoc.who.int/hq/ 1992/WHO MCH MSM 92.2.pdf

17. Iron studies: Normal and abnormal [http://books.google.com.tr/ books?id=7QCkLuT4iRYC\&pg=RA1-PA208\&lpg=RA1PA208\&da=iron+saturation+less+than+10\%25+indicator++depleted+iro

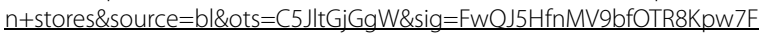
Dr fw\&hl=tr\&ei=3tTySpazGJSUnwOt2KWwAw\&sa=X\&oi=book result\&ct =result\&resnum $=1 \& v e d=0 C A g Q 6 A E w A A \# v=$ onepage $\& q=\& f=$ false]

18. Fielding J: Serum Iron and Iron Binding Capacity. New-york: Churchill Livingstone; 1980:15-37.

19. Turkey: DHS, 2003 - 2003 Final Report (English) [http:// www.measuredhs.com/pubs/ pub details.cfm? $\mid \mathrm{D}=484 \&$ ctry $i d=58 \&$ SrchTp=ctry\&flag=sur \&cn=Turkey

20. Eastern Anatolia Project Master Plan [http://ekutup.dpt.gov.tr/ bolgesel/dap/ing/plan.pdf]

21. Council of Europe HDSE Report on Turkey [http://www.coe.int/t/e/ social cohesion/hdse/2 hdse reports/1 country reports/ $\mathrm{L}$ Report\%20TURKEY.asp]

22. Beştepe $\mathrm{G}$, Bilgin N: Afyon ili 2 ve 4 No'lu sağhk ocaklarındaki gebelerde anemi prevalansı ve anemiyi etkileyen bazı faktörlerin incelenmesi, (A Study on the Prevalance of Anaemia and Some Influential Factors for Anaemia in Pregnant Women Who are Living in the Provinces of Health Centers Number II and IV in Afyon). Sa ğl Ik ve Toplum 2002, 12(2):43-53.

23. Pirinçci $E, A c ̧ ı k Y$, Bostancı M, Eren S, Beritanlı H: Elazı ̆ il merkezinde yaşayan gebelerde anemi prevalansı (Prevalence of Anaemia in Pregnant Women in Elazığ). Fırat Üniversitesi Sa ğık Bilimleri Tıp Dergisi 2001, 15(3):449-54.
24. Milman N: Prepartum anaemia: prevention and treatment. Ann Hematol 2008, 87:949-959.

25. Dim CC, Onah HE: The prevalence of anaemia among pregnant women at booking in Enugu, South Eastern Nigeria. MedGenMed 2007, 9(3):11.

26. Idowu OA, Mafiana CF, Dapo S: Anaemia in pregnancy: a survey of pregnant women in Abeokuta, Nigeria. Afr Health Sci 2005, 5(4):295-9.

27. Demographic and Health Survey TDHS-2003 [http:// www.hips.hacettepe.edu.tr/tnsa2003/data/English/chapter04.pdf

28. Okcuoglu A, Arcasoy A, Minnich V, Tarcon Y, Cin S, Yörükoğlu O, Demirag B, Renda F: Pica in Turkey. 1. The incidence and association with anemia. Am J Clin Nutr 1966, 19:125-31.

29. Federman DG, Kirsner RS, Federman GS: Pica: are you hungry for the facts? Conn Med 1997, 61(4):207-9.

30. Rose EA, Porcerelli JH, Neale AV: Pica: common but commonly missed. J Am Board Fam Pract 2000, 13(5):353-8.

31. Baig-Ansari N, Badruddin SH, Karmaliani R, Harris H, Jehan I, Pasha O, Moss N, McClure EM, Goldenberg RL: Anaemia prevalence and risk factors in pregnant women in an urban area of Pakistan. Food Nutr Bull 2008 , 29(2):132-9.

32. Pasricha SR, Caruana SR, Phuc TQ, Casey GJ, Jolley D, Kingsland S, Tien NT, MacGregor L, Montresor A, Biggs BA: Anaemia, iron deficiency, meat consumption, and hookworm infection in women of reproductive age in northwest Vietnam. Am J Trop Med Hyg 2008, 78(3):375-81.

33. Wolmarans $P$, Dhansay MA, Mansvelt EP, Laubscher JA, Benadé AJ: Iron status of South African women working in a fruit-packing factory. Public Health Nutr 2003, 6(5):439-45.

34. Mennen L, Hirvonen T, Arnault N, Bertrais S, Galan P, Hercberg S: Consumption of black, green and herbal tea and iron status in French adults. Eur J Clin Nutr 2007, 61(10):1174-9.

35. Temme EH, Van Hoydonck PG: Tea consumption and iron status. Eur J Clin Nutr 2002, 56:379-86.

36. Dangour AD, Hill HL, Ismail SJ: Haemoglobin status of adult nonpregnant Kazakh women living in Kzyl-Orda region, Kazakhstan. Eur J Clin Nutr 2001, 55(12):1068-75

37. Zijp IM, Korver O, Tijburg LB: Effect of tea and other dietary factors on iron absorption. Crit Rev Food Sci Nutr 2000, 40(5):371-98.

38. Speedyp AW: Global Production and Consumption of Animal Source Foods. J Nutr 2003, 133(Suppl 2):4048-4053.

39. Alemdaroglu NC, Dietz U, Wolffram S, Spahn-Langguth $H$, Langguth $P$. Influence of green and black tea on folic acid pharmacokinetics in healthy volunteers: potential risk of diminished folic acid bioavailability. Biopharm Drug Dispos 2008, 29(6):335-48.

40. Dr. Lütfi Kırdar Kartal Ĕ̆itim Araştırma Hastanesi gebe polikliniğine bașvuran gebelerde anemi prevalansı ve etyolojisi (Prevalence and etiology of anaemia among pregnant women attended to pregnancy outpatient clinic at Dr. Lütfi Kırdar Kartal training and research hospital) [http://www.istanbulsaglik.gov.tr/w/tez/pdf/aile hekimligi/ dr fulya bayer pehlivanoglu.pdf]

41. Koc A, Kocyigit A, Soran M, Demir N, Sevinc E, Erel O, Mil Z: High frequency of maternal vitamin B12 deficiency as an important cause of infantile vitamin B12 deficiency in Sanliurfa province of Turkey. Eur J Nutr 2006, 45(5):291-7.

42. Vanderjagt DJ, Brock HS, Melah GS, El-Nafaty AU, Crossey MJ, Glew RH: Nutritional factors associated with anaemia in pregnant women in northern Nigeria. J Health Popul Nutr 2007, 25(1):75-81

43. Oner N, Vatansever U, Karasalihoğlu S, Ekuklu G, Celtik C, Biner B: The prevalence of folic acid deficiency among adolescent girls living in Edirne, Turkey. J Adolesc Health 2006, 38(5):599-606.

44. Tuncbilek E, Boduroglu K, Alikasifoglu M: Neural tube defects in Turkey: prevalence, distribution and risk factors. Turk J Pediatr 1999, 41:299-305.

45. Hertrampf E, Cortés F: Folic Acid Fortification of Wheat Flour: Chile. Nutr Rev 2004, 62(6 Pt 2):S44-8.

46. Dugdale AE: Predicting iron and folate deficiency anaemias from standard blood testing: the mechanism and implications for clinical medicine and public health in developing countries. Theor Biol Med Model 2006, 3:34.

47. Iron deficiency anaemia; Assessment, Prevention and Control; A guide for programme managers [http://whqlibdoc.who.int/hq/2001/ WHO NHD 01.3.pdf

48. Cogswell ME, Parvanta I, Ickes L, Yip R, Brittenham GM: Iron supplementation during pregnancy, anaemia, and birth weight: a randomize controlled trial. Am J Clin Nutr 2003, 78(4):773-81. 
49. Özcan A, Sarper N, Samlı G: Nutritional Vitamin B12 Deficiency In Infants: Report Of Three Cases. Turkiye Klinikleri J Pediatr 2004,

13:153-159.

50. Clarke R, Grimley EJ, Schneede J, Nexo E, Bates C, Fletcher A, Prentice A, Johnston C, Ueland PM, Refsum H, Sherliker P, Birks J, Whitlock G, Breeze E, Scott JM: Vitamin B12 and folate deficiency in later life. Age Ageing 2004, 33(1):34-41.

51. Gebelerde Demir Destek Programı Uygulaması Genelgesi 2007/6 Instruction rules for iron supplement program towards pregnant women 2007/6 [http://www.saglik.gov.tr/TR/Genel/ BelgeGoster.aspx?F6E10F8892433CFF8FE9074FF19B0005CF18F145EBDBE B5B].

52. Special supplemental nutrition program for women, infants, and children (WIC) [http://books.google.com.tr/ books? id=vS880gTOl1 MC\&pg=PA129\&/pg=PA129\&dq=iron+assessment +of+pregnant+women+enrolled+in+the+Special+Supplemental+Progr am+for+Women, +Infants, +and+Children+(WIC\&source=bl\&ots=ttkL1nj 44\&sig=311ZgyjbjqoK37ZATyHHSnCjCQ\&hl=tr\&ei=VDuBSstunsacA9vJzP

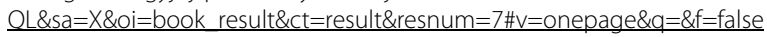

53. Swensen AR, Harnack $L$, Ross JA: Nutritional assessment of pregnant women enrolled in the Special Supplemental Program for Women, Infants, and Children (WIC). J Am Diet Assoc 2001, 101(8):903-8.

\section{Pre-publication history}

The pre-publication history for this paper can be accessed here: http://www.biomedcentral.com/1471-2458/10/329/prepub

doi: 10.1186/1471-2458-10-329

Cite this article as: Karaoglu et al., The prevalence of nutritional anemia in pregnancy in an east Anatolian province, Turkey BMC Public Health 2010, 10:329

Submit your next manuscript to BioMed Centra and take full advantage of:

- Convenient online submission

- Thorough peer review

- No space constraints or color figure charges

- Immediate publication on acceptance

- Inclusion in PubMed, CAS, Scopus and Google Scholar

- Research which is freely available for redistribution 